\title{
Penggunaan Media Audiovisual Dengan Power Point Di Tengah Pandemi Dalam Pembelajaran Pendidikan Kewarganegaraan Di Madrasah Ibtidaiyah
}

\author{
Heri Hidayat ${ }^{1}$, Heny Mulyani' ${ }^{2}$, Dini Arlina ${ }^{3}$, Dea Lita Salsabila ${ }^{4}$, Delfianti Azzahra ${ }^{5}$ \\ ${ }^{12345}$ Universitas Islam Negeri Sunan Gunung Djati Bandung
}

\begin{tabular}{|c|c|}
\hline (A) Check for updates open $\partial_{\text {access }}$ cc) (i) (2) & DOI : 10.47400/jiees.v1i2.28 \\
\hline Sections Info & ABSTRACT \\
\hline $\begin{array}{l}\text { Article history: } \\
\text { Received: Desember } 262020 \\
\text { Accepted: Desember } 282020 \\
\text { Published online: Desember } 30 \\
2020\end{array}$ & $\begin{array}{l}\text { The use of audiovisual media is a strategy in student learning to determine the effect } \\
\text { and development of teacher performance on students. During the Covid-19 pandemic, } \\
\text { Civics learning, especially in Islamic Elementary School and Elementary School, } \\
\text { contained audiovisual learning using Power point as a tool for presenting material } \\
\text { that was well known among users of personal computers and laptops. In this study }\end{array}$ \\
\hline $\begin{array}{l}\text { Keywords: } \\
\text { Covid-19 } \\
\text { Technology } \\
\text { Audio Visual Media } \\
\text { Power Point } \\
\text { Civics Education }\end{array}$ & $\begin{array}{l}\text { using several research methods in the form of secondary data with observations and } \\
\text { experiences in accordance with the theme of learning through the media as well as } \\
\text { utilizing library resources. Through the Audiovisual facility with Power Point, it } \\
\text { shows the results of research in the form of the development of the reasoning power of } \\
\text { students who are capable of actually being and increasing the learning process for } \\
\text { students to a more professional level in the use of learning technology. }\end{array}$ \\
\hline
\end{tabular}

\section{INTRODUCTION}

Seluruh negara dibelahan bumi saat ini sedang mengalami musibah wabah virus corona yang telah menyebar secara luas di dunia, salah satunya di Negara Asia Tenggara yaitu di Indonesia. WHO (World Health Organization atau Badan Kesehatan Dunia) secara resmi mendeklarasikan virus Covid-19 sebagai pandemi pada awal Maret 2020. Di Indonesia penyebaran covid 19 cukup tinggi lonjakan di atas 1000 terus mengalami kenaikan. Hal tersebut mempengaruhi perubahan dan pembaharuan kebijakan untuk diterapkan di Indonesia. Dampak covid-19 terhadap dunia pendidikan berdampak sangat besar dirasakan oleh berbagai pihak terutama guru, kepala sekolah, peserta didik dan orang tua. Kebijakan baru juga terjadi pada dunia pendidikan merubah pembelajaran yang awalnya harus datang ke kelas, dalam hal ini menjadi cukup di rumah saja. Anjuran dari pemerintah untuk stay at home dan physical social distancing harus diikuti dengan perubahan modus belajar tatap muka menjadi online. Agar dapat memutus mata rantai penyebaran covid-19 bisa terwujud, dan cita-cita tujuan negara dalam bidang pendidikan akan tercapai.

Menteri Pendidikan dan Kebudayaan Nadiem Makarim mengeluarkan surat edaran Nomor 3 Tahun 2020 mengenai Pencegahan Covid-19 di wilayah pendidikan. Beliau mengimbau kepada seluruh pemangku kepentingan di dunia pendidikan untuk melakukan langkah-langkah dalam pencegahan penyebaran virus corona. Salah satu kebijakan yang diambil adalah supaya proses belajar mengajar menggunakan metode pembelajaran daring. Pembelajaran daring ini sesuai dengan surat edaran Mendikbud yang salah satu poin dalam surat itu adalah siswa dapat belajar di rumah, melalui konferensi video, dokumen digital, dan saranan daring lainnya (Rahmawati, 2020).

Adanya pandemi covid-19 ini membuat peserta didik mau tidak mau, suka idak suka harus berhadapan dengan teknologi untuk mendukung pembelajaran. Sekolah 
harus menyiapkan alat dan bahan untuk menyiapkan bahan ajar dalam pembelajaran jarak jauh. Bagi seorang guru pula harus bisa menciptakan metode pembelajaran yang menurut siswa tidak membosankan dan sebisa mungkin menciptakan suasana pembelajaran online secara efektif dan membuat siswa menjadi aktif. Untuk menjadi pembelajar online yang aktif, seorang siswa tertentu memerlukan cara tertentu pula, ia harus dihadapkan pada berbagai pengalaman belajar untuk menjadi pembelajar online (daring) yang lebih fleksibel (Zapalska 2006). Meskipun banyak orang tua yang mengeluh akan pembelajaran daring ini, namun kegiatan pembelajaran daring ini merupakan jalan yang terbaik untuk kebaikan dan keselamatan kita bersama. (Simmons 2002).

Adanya pembelajaran daring ini merupakan keadaan dimana kita bisa memanfaatkan teknologi yang ada, seperti hal nya melaksanakan pembelajaran daring melalui komputer atau telepon selular. Pembelajaran daring dapat bersifat interaktif sehingga peserta mampu berinteraksi dengan komputer atau telepon selular sebagai media penghubung belajarnya. Sebagai alat perantara interaksi peserta didik dengan pengajar dapat menggunakan akses internet melalui berbagai aplikasi yang mudah penggunaannya seperti dengan media digital, yaitu aplikasi WhatsApp, Zoom Meeting, Google Classroom, Youtube dan sebagainya. Aplikasi tersebut merupakan aplikasi yang biasa digunakan oleh siswa, sebagai bahan utama agar kegiatan belajar dapat tetap berjalan sesuai dengan aturan yang berlaku di Kementerian Pendidikan dan Kebudayaan. Dengan disediakannya media teknologi ini, siswa akan semakin mudah dan lebih bersemangat untuk belajar, karena semua sudah bisa dilakukan kapan pun dan dimanapun. Sehingga orang tua tidak perlu khawatir karena media digital tersebut dapat mudah diawasi oleh para orang tua untuk menjaga anaknya agar selalu menggunakan media teknologi dengan baik dan benar.

Akan tetapi dari penggunaan daring tersebut terdapat beberapa dampak negatif seperti halnya kurang pahamnya pendidik terhadap konsep pembelajaran daring, implementasi pembelajaran daring yang kurang maksimal, dan keterbatasan atas fasilitas untuk pembelajaran daring. Hal ini tentu dapat mengganggu hasil dari pembelajaran daring tersebut dan harus segera diatasi. Bagi guru hendaknya dapat memaksimalkan pembelajaran daring dengan memahami konsep dari pembelajaran daring itu sendiri. Peserta didik pun juga harus menyiapkan kiat-kiat agar pembelajaran daring dapat terlaksana dengan maksimal. (Kualita Pendidikan Indonesia, 2020)

Sehingga perlunya penggunaan media pembelajaran yang tepat agar proses pembelajaran dapat terlaksana dengan baik walapun hanya berbasis daring. Penerapan model pembelajaran dengan menggunakan tampilan Microsoft PowerPoint dan ditunjang dengan penggunaan media audio visual tentunya dapat meningkatkan kualitas pembelajaran. Hal tersebut terjadi karena audio visual merupakan media yang memberikan dorongan dan rangsangan kepada siswa untuk belajar dengan aktif serta melatih siswa untuk memiliki keterampilan bertanya dan menyimak (Khaulani et al., 2019). Sejalan dengan pendapat Sulfemi \& Mayasari (2019) mengatakan bahwa media audio visual adalah alat bantu penyajian materi yang merangsang siswa untuk belajar dengan efektif untuk memperoleh pengetahuan dan keterampilan tertentu.

Audio visual dipilih karena melibatkan dua unsur alat indera untuk memperoleh dan mengolah informasi. Media audio visual dapat menciptakan suasana 
pembelajaran menjadi lebih menarik sehingga siswa tertarik untuk belajar (Pitriani et al., 2017). Media ini dapat memperkaya lingkungan belajar karena memiliki keefektifan. Keefektifan media ini terletak pada informasi yang disampaikan lebih mudah dipahami oleh siswa sehingga memberikan dampak yang nyata terhadap ranah kognitif, afektif dan psikomotor siswa (Fatimah et al., 2019). Dengan penerapan media ini dapat menjadi jembatan untuk guru menyampaikan materi pembelajaran secara efektif sehingga tujuan pembelajaran dapat terlaksana dengan baik.

Penggunaan media tersebut dapat digunakan dalam pembelajaran Pendidikan Kewarganeragaan karena negara Indonesia selain sedang mengalami pandemi tetapi juga dalam pendidikan di Indonesia sedang menghadapi masalah yang besar dari adanya tantangan globalisasi yang semakin luas di segala aspek kehidupan dan juga pendidikan. Menurut Sutrisno dan Moerdiono dalam Sutrisno (2018) untuk itu diperlukan adanya rekontruksi dalam dunia pendidikan untuk menyiapkan calon warga global. Warga global merupakan bentuk pengembangan nilai-nilai dasar kemanusiaan dalam pengembangan hak dan kewajiban negara untuk menjalankan tugasnya. Salah satu bentuk pengembangan warga dalam perkembangan zaman perlu diperhatikan, apalagi salah satunya pembelajaran yang dapat digunakan yaitu dalam pembelajaran Pendidikan Kewarganegaraan terutama bagi anak-anak disekolah dasar. Karena melalui Pendidikan Kewarganegaraan ini, diharapkan dapat membentuk kepribadian utama warga negara Indonesia yang muda, cerdas, baik dan dapat diandalkan. Untuk bisa membentuk warga negara Indonesia yang cerdas, baik dan dapat diandalkan maka harus memiliki dua sifat yakni sikap yang peduli terhadap kondisi masyarakat dan sikap untuk bisa melakukan perubahan yang lebih baik.

Maka dengan penulis mengambil sebuah judul "Penggunaan Media Audiovisual dengan PowerPoint di Tengah Pandemi dalam Pembelajaran Pendidikan Kewarganegaraan di Madrasah Ibtidaiyah". Tujuan utama untuk terjadinya proses belajar yang optimal dan pemanfaatan media powerpoint dalam pembelajaran pendidikan kewarganegaraan memberikan alternatif yang terbaik untuk meningkatkan kualitas proses dan perilaku belajar siswa yang mencakup aspek kognitif, afektif, dan psikomotorik. Sehingga siswa dapat menyimak kemudian memahami materi yang diberikan dengan baik sehingga kebermaknaan pembelajaran pendidikan kewarganegaraan dapat tercapai dan dalam pembelajaran yang menarik diharapkan dapat membentuk kecerdasan, kepribadian, akhlak mulia serta keterampilan para generasi muda dalam menghadapi tantangan kemajuan zaman.

\section{RESEARCH METHOD}

Penelitian ini termasuk dalam studi literatur. Jenis data yang dikumpulkan berupa data sekunder berupa hasil-hasil penelitian dari berbagai artikel yang sesuai dengan pembahasan judul, dan pengamatan atau pengalaman, sumber pustaka dan dokumen yang sesuai dengan tema pembelajaran melalui media dan berbasis proyek, pada riset pustaka, penelusuran pustaka tidak hanya untuk langkah awal menyiapkan kerangka penelitian akan tetapi sekaligus memanfaatkan sumber-sumber perpustakaan untuk memperoleh data penelitian. Data-data yang didapatkan, kemudian dikumpulkan, dikompilasi, dikaji, dianalisis, dan disimpulkan sehingga mendapatkan rekomendasi mengenai studi literatur. 


\section{RESULTS AND DISCUSSION}

Wabah yang sedang terjadi di seluruh dunia yaitu infeksi virus Corona atau lebih sering disebut COVID-19 (Corona Virus Disease 2019) dan pertama kali ditemukan di kota Wuhan, China pada akhir Desember 2019. Virus ini menular dengan sangat cepat dan telah menyebar ke hampir semua negara, termasuk Indonesia hanya dalam waktu beberapa bulan. Hal tersebut membuat beberapa negara menerapkan kebijakan untuk memberlakukan lockdown dalam rangka mencegah penyebaran virus Corona. Di Indonesia sendiri, diberlakukan kebijakan Pembatasan Sosial Berskala Besar (PSBB) untuk menekan penyebaran virus ini (Pane, 2020).

Mengenai problematika belajar dan pembelajaran daring pada masa pandemi ini sangat di prioritaskan, terlebih lagi dalam perubahan belajar dan pembelajaran yang berpengaruh terhadap dunia pendidikan. Keadaan ini menjadi hal yang tidak biasanya, seperti pembelajaran dilakukan secara langsung dikelas antara guru dan siswa bertatap muka yang kini belajar dilakukan secara daring dari rumah masing-masing. Hal ini harus dilakukan untuk menekan laju penyebaran virus corona di Indonesia. Tentunya pihak yang berwajib sangat mempertimbangkan problematika tersebut agar pencapaian kependidikan di negara Indonesia ini tetap berjalan dengan lancar sesuai dengan aturan yang telah ditetapkan. Sehingga Menteri Pendidikan dan Kebudayaan menindak lanjuti kebijakan tersebut dengan mengeluarkan Surat Edaran Nomor 4 Tahun 2020 tentang pelaksanaan kebijakan pendidikan dalam masa darurat penyebaran Corona khusunya pada proses belajar dari rumah di laksanakan dengan ketentuan seperti belajar dari rumah melalui pembelajaran daring atau jarak jauh dilaksanakan untuk memberikan pengalaman belajar yang bermakna bagi siswa, tanpa terbebani tuntutan memuntaskan seluruh capaian kurikulum untuk kenaikan kelas maupun kelulusan, dengan belajar dari rumah dapat di fokuskan pada pendidikan kecakapan hidup antara lain mengenai pandemic Covid-19, aktivitas dan tugas pembelajaran belajar dari rumah dapat bervariasi antar siswa, sesuai minat dan kondisi masing-masing termasuk mempertimbangkan kesenjangan akses atau fasilitas belajar di rumah dan bukti atau produk aktivitas belajar dari rumah diberi umpan balik yang bersifat kualitattif yang berguna dari guru, tanpa diharuskan memberi skor atau nilai kuantitatif. Kebijakan tersebut dapat disesuikan dengan kondisi saat ini khususnya dalam keterkaitan antar pendidik dan peserta didik guna apat menyeimbangkan dengan strategi pembelajaran. Maka demikian kebijakan tersebut ini menjadi acuan terhadap tenaga pendidik untuk selalu mengarahkan pola pembelaran dengan profesional. (Mulianti, 2020).

Dari wawancara terhadap peserta didik tentang dampak yang dialami saat pandemi terhadapat proses pengajaran menyatakan, bahwa persiapannya dalam mengikuti pembelajaran ecara daring sangat kurang karena untuk belajar secara tatap muka langsung saja masih memiliki kendala dalam pembelajaran, apalagi dengan online ini pembelajarannya kurang efektif karena keterbatasan interaksi kepada pengajar dan yang biasanya mengikuti pembelajaran di kelas dengan teman-temannya tetapi harus dihadapkan dengan belajar di rumah sendiri sehingga peserta didik merasa jenuh. Karena pandemi ini mengharuskan peserta didik untuk belajar jarak jauh dan belajar dirumah dengan bimbingan dari orang tua. (Mastura \& Santaria, 2020).

Pada proses pembelajaran di tiap-tiap sekolah terdapat berbagai penerapan yang di tetapkan. Masing-masing memiliki kinerja dengan potensi yang sudah di rencanakan 
dengan sebaik mungkin. Adapun unsur keterkaitan dengan teknologi yang bertujuan untuk meminimalisir keadaan dalam strategi pembelajaran untuk terlaksanaknya hasil belajar yang efektif bagi peserta didik. Seperti dalam penerapan pembelajaran PKn dengan teknologi Media Visual, yang dipergunakan untuk meningkatkan hasil belajar pada siswa kelas V SD Inpres 012 Bajawali kecamatan Lariang kabupaten Mamuju Utara, yaitu dalam pelaksanaannya menunjukkan bahwa pembelajaran dikelas belum memenuhi batas tuntas yang ditetapakan, belum tercapainya tujuan yang diharapkan. penyebabnya hasil belajar siswa kurang yaitu kurang terjadinya interaksi antara guru dan siswa atau sebaliknya karena hanya menggunakan metode ceramah dan tidak menggunakan teknologi sebagai alat media pembelajarannya, sehingga siswa kurang aktif dalam proses pembelajaran berlangsung. Maka dari itu dengan memunculkan proses pembelajaran yang menggunakan media visual ini, menjadi tampak terjadinya peningkatan yang cukup baik. Hal ini menunjukan dan membuktikan bahwa penggunaan media visual cukup efektif dalam proses pembelajaran di kelas untuk meningkatkan daya nalar siswa, kreatifitas, dan kemampuan mengkaitkan satu konsep dengan konsep yang lain sehingga berdampak pada hasil belajar yang baik bagi siswa ataupun pada guru itu sendiri. Maka peningkatan proses pembelajaran yang diterapkan ini cukup berdampak baik, sehingga mampu dikembangkan dan di beri apresiasi serta di pergunakan juga terhadap instansi-instansi lainnya. Karena dengan perkembangan pembelajaran melalui Media Visual cukup berpengaruh terhadap proses daya belajar siswa sehingga patut untuk direalisasikan dengan sebaik mungkin. (Polymaroa, Kapile, \& Hamid, hal. 89-91)

Terutama dalam pembelajaran pendidikan kewarganegaraan sangatlah penting bagi perserta didik karna bertujuan membina dan mengembangkan agar menjadi warga negara yang baik, di samping itu pendidikan kewarganegaraan mengajarkan untuk memahami dan bisa melaksanakan hak dan kewajiban secara jujur dan demokratis dalam kehidupannya sebagai warga negara yang terdidik yang mana ini merupakan hal yang sangat mendasarkan dalam pelajaran PKn mengajarkan tenggang rasa, toleransi dan bisa saling menghormati satu sama lain. Karena pada akhirnya nanti para peserta didik akan terjun langsung ke masyarakat secara langsung, oleh sebab itu pendidikan kewarganegaraan sangatlah penting disampaikan sejak dini kepada anakanak. Jika seorang pengajar kurang mampu menguasai metode yang bisa membuat siswa tidak dapat memahami pembelajaran yang menjadikannya tujuan penyampaian pada mata pelajaran pendidikan kewarganegaraan tidak tersampaikan dengan baik. (Hidayat et al., 2020)

Sehingga dalam dunia pendidikan, seorang guru harus senantiasa barusaha memunculkan motif tertentu di dalam diri anak didiknya. Cara menumbuhkan motif tersebut bisa bermacam-macam. Dengan melalui proses belajar mengajar dengan menggunakan media audio visual, yang sangat berbeda dengan pengajaran konvensional. Pengalaman melihat dan mendengar membuat anak didik akan lebih mudah menginterpretasikan materi atau informasi yang disampaikan oleh guru. Belajar dengan media pengajaran yang bervariasi sangat membantu anak didik dalam memahami penjelasan dari guru. Anak didik sendiri cenderung lebih antusias bila dihadapkan pada realitas yang dipersentasikan secara visual. Salah satunya dalam menggunakan Microsoft Power Point, saat ini, menjadi software yang cukup sering 
digunakan untuk membuat persentasi visual dalam proses belajar mengajar. Software ini relative mudah untuk dipelajari dan sangat user friendly. (Mahfud, 2017).

Microsoft Power Point mempunyai banyak kelebihan, antara lain; mampu menampilkan tulisan dan gambar dengan bermacam warna, dapat diselengi dengan gambar hidup atau film, proses penulisan yang mudah (bila salah ketik, tinggal di delete-red), pola tulisan dapat dipilih sesuai dengan selera kita dan dapat pula menyisipkan suara (lagu) sehingga presentasi menjadi lebih menarik dan atraktif. Penggunaan media power point ini juga dapat di pindahkan ke fitur PDF. Karena ketika guru telah menyelesaikan materi di Power Point, tentu setelah itu guru membagikan materinya kepara peserta didik supaya mereka memahami poin-poin yang akan dibahas. Tapi, kadang beberapa dari mereka tidak menggunakan platform Microsoft, sehingga file yang telah didistribusikan tidak bisa dibuka. Nah, dengan adanya fitur ini, setiap peserta didik dapat melihat dokumen yang dibagikan. Di samping itu, fitur export file ke PDF sangat berguna bila peserta didik tersebut akan mem-print slide. Apalagi, format PDF telah di support oleh berbagai platform, sehingga peserta didik bisa mencetaknya melalui platform dan mesin apa saja. (Amalia., A., I, 2014).

Keuntungan penggunaan media pembelajaran online yaitu pembelajarannya bersifat mandiri dan interaktivitas yang tinggi, mampu meningkatkan tingkat ingatan kepada peserta didik, sehingga memberikan lebih banyak pengalaman belajar, dengan teks, audio, video dan animasi yang semuanya digunakan untuk menyampaikan informasi, dan juga memberikan kemudahan menyampaikan, meng-update isi, mengunduh, para siswa juga bisa mengirim email kepada siswa lain, mengirim komentar pada forum diskusi, memakai ruang obrolan (chatting), hingga link video conference untuk berkomunikasi langsung menjadikan siswa mengenal dan mengetahui penggunaan teknologi pembelajaran. (Dryden et al., 2001)

Dengan demikian dalam pembelajaran pendidikan kewarganegaraan mampu memanfaatkan teknologi informasi berupa Power Point yang dapat diharapkan untuk mengatasi proses belajar mengajar agar berjalan dengan baik meskipun harus menghadapi terpaan pandemi Covid-19. Karena teknologi Power Point ini mampu meningkatkan aktivitas utama dalam pendidikan yang berlangsung dalam proses terencana dengan keterlibatan komponen yang saling terikat antara teknologi dengan pembelajaran khusus nya bagi siswa Sekolah Dasar maupun Madrasah Ibtidaiyah. Hal ini menjadikan perubahan awal bagi siswa untuk mengetahui pemanfaatan dari teknologi yang semakin berkembang, karena kelebihan dalam belajar Audiovisual dengan menggunakan media Power Point dapat berguna kapan saja dan dimanapun, bahkan sampai ke jenjang berikutnya. (Mulianti, 2020).

\section{CONCLUSIONS}

Pembelajaran daring yang dihadapi siswa memang terlihat tidak efektif, karena banyaknya siswa yang jenuh dengan adanya pembelajaran secara online, kurangnya interaksi antara guru dan teman-temannya tidak seperti halnya kegiatan di kelas. Sehingga perlunya menemukan media yang bisa menarik semangat dalam pembelajaran online. Yaitu, dengan memanfaatkan teknologi yang sudah semakin canggih di zaman sekarang ini tanpa ada batasan apapun dengan mengakses jaringan internet, melalui media pembelajaran powerpoint yang digunakan ini bisa membantu 
siswa dalam memahami materi dengan mudah yakni dengan melalui powerpoint ini yang mana dapat menampilkan beberapa macam media, yakni media audio visual, media gambar, maupun media audio saja. Belajar menggunakan media pembelajaran powerpoint juga dapat meningkatkan pemahaman siswa mengenai materi yang diajarkan guru, karena dengan melalui powerpoint dapat memunculkan berbagai variasi yang terdapat dalam fiturnya. Awalnya sebelum menggunakan media dinyatakan tidak sesuai dengan apa yang diharapkan oleh guru, karena siswa terlihat kurang aktif. Namun jika siswa menggunakan media pembelajaran powerpoint, mungkin selain dapat mempermudah dalam memahami materi yang dijelaskan oleh guru, melalui powerpoint juga dapat meningkatkan hasil belajar siswa yakni dalam pembelajaran. Terdapat kelebihan yang dimiliki oleh Microsoft powerpoint yakni mampu menampilkan tulisan dan gambar dengan bermacam warna, dapat diselingi dengan gambar hidup atau film, proses penulisan yang mudah, pola tulisan dapat dipilih sesuai dengan selera yang kita inginkan dan dapat pula menyisipkan suara atau lagu sehingga presentasi atau penyampaian materi pengajaran menjadi lebih menarik dan atraktif untuk siswa. Dan melalui Microsoft power point juga dapat menciptakan sikap mandiri terhadap siswa, karena teknologi Power Point ini mampu meningkatkan aktivitas utama dalam pendidikan yang berlangsung dalam proses terencana dengan keterlibatan komponen yang saling terikat antara teknologi dan pendidikan dengan pembelajaran khusus nya bagi siswa Sekolah Dasar maupun Madrasah Ibtidaiyah.

\section{ACKNOWLEDGEMENTS}

Penulis mengucapkan terima kasih yang sebesar-besarnya kepada PGMI FTK Universitas Islam Negeri Sunan Gunung Djati Bandung atas dukungan dan bantuan dalam menyelesaikan penelitian ini.

\section{REFERENCES}

Amalia, I.A. (2014). Powe Point Sebagai Alternatif. Jurusan PGRA IAIN Syekh Nurjati Cirebon.

Dryden, Gordon, \& Vos. J. (2001). Revolusi Cara Belajar. Bandung: Kaifa.

Fatimah, Selviana, Widyastutik, O., \& Suwarni, L. (2019). Efektifitas Media Audio Visual (Video) Terhadap Peningkatan Pengetahuan dan Sikap Kelompok Masyarakat Tentang Progma G1R1J. Jurnal Kesehatan Masyarakat Katulistiwa, 4447.

Hidayat, H., Mulyani, H., Nurhasana, S.D., Khairunnisa, W., \& Sholihah, Z. (2020). Peranan Teknologi Dan Media Pembelajaran Bagi Siswa Sekolah Dasar di Dalam Pembelajaran Pendidikan. Jurnal Pendidikan Kewarganegaraan Undiksha, 3-4. Indonesia.

Khaulani, F., \& Noviana, E. (2019). Penerapan Metode Brainstorming dengan Bantuan Media Gambar Grafis Untuk Meningkat Hasil Belajar PKN siswa Kelas V SD Negeri 009 Pulau Kecamatan Bangkinang Kabupaten Kampar. Jurnal PAJAR (Pendidikan Dan Pengajaran), 18-25.

Kualita Pendidikan Indonesia. (2020). Dampak Positif Pembelajaran Daring. Kpi 
Mahfud, M. (2017). Audio Visual Sebagai Media Belajar Siswa. GURARU guru era baru.

Mastura, \& Santaria, R. (2020). Dampak Pandemi Covid-19 terhadap Proses Pengajaran bagi Guru dan Siswa. Jurnal Studi Guru dan Pembelajaran, 291-292.

Media Visual Untuk Meningkatakan Hasil Belajar Pada Siswa Kelas V SDN Inperes 012 Bajawali Kecamatan Mariang Kabupaten Mamuju Utara. JUrnal Kreatif Tadulako Online Vul.3 No. 2, 88.

Mulianti. (2020). Problematika Belajar dan Pembelajaran Daring Pada Masa Pandemi Covid-19. 3-4.

Pane, M.D.C. (2020). Virus Corona. Alodokter.com.

Pitriani, N.W., Ardana, I.K., \& Kristiantari, R. (2017). Pengaruh Model Pembelajaran Think Pair Share Berbantuan Audio Visual Terhadap Kompetensi Pengetahuan IPS. MIMBAR PGSD, 1-9.

Polymaroa, P., Kapile, C., \& Hamid, A. (t.thn.). Penerapan Pembelajaran PKn Dengan

Rahmawati, N.D. (2020). Positif Negatif Belajar Lewat Daring. Kompasiana.com.

Simmons, D.E. (2002). The Forum Report : E-learning Adoption Rates and Barriers. The ASTD e-learning Handbook, 19-23.

Sulfemi, W.B., \& Mayasari, N. (2019). Peranan Model Pembelajaran Value Clarification Technique Berbantuan Media Audio Visual Untuk Meningkatkan Hasil Belajar IPS. Jurnal Pendidikan, 53-68.

Sutrisno. (2018). Peran Pendidikan Kewarganegaraan Dalam Membangun Warga Negara Global. 42-43.

Taseman, Iman Rasiman, Arumi Puji Lestari, Atik Anturichana, Hanyfa Maulidiyah, H. H. (2020). IMPLEMENTASI EVALUASI SOAL PEMBELAJARAN IPS THE IMPLEMENTATION OF LEARNING EVALUATION ON SOCIAL STUDIES BASED ON 2013 CURRICULUM AT MI ASSYAFI' IYAH. AULADUNA: Jurnal Pendidikan Dasar Islam, 7(1), 74-80

Taseman. (2020). Pemanfaatan Media Visual Pada Pembelajaran IPS Di MI Darul Mutaallimin Sidoarjo. BADA’A: Jurnal Ilmiah Pendidikan Dasar, 2(1), 86-97.

Zapalska, A. B. (2006). Learning Styles and Online Education. Campus-Wide Information Systems.

Author (s) :

\section{Heri Hidayat}

Jurusan Pendidikan Guru Madrasah Ibtidaiyah, Fakultas Tarbiyah dan Keguruan.

Universitas Islam Negeri Sunan Gunung Djati, Bandung, Indonesia.

Jl. A.H. Nasution No.105, Cibiru, Bandung 40614, Indonesia.

Email: herihidayat@uinsgd.ac.id

\section{Heny Mulyani}

Jurusan Pendidikan Guru Madrasah Ibtidaiyah, Fakultas Tarbiyah dan Keguruan.

Universitas Islam Negeri Sunan Gunung Djati, Bandung, Indonesia.

Jl. A.H. Nasution No.105, Cibiru, Bandung 40614, Indonesia. 
Email: henymulyani@uinsgd.ac.id

\section{Dea Lita Salsabila (Corresponding Author)}

Jurusan Pendidikan Guru Madrasah Ibtidaiyah, Fakultas Tarbiyah dan Keguruan.

Universitas Islam Negeri Sunan Gunung Djati, Bandung, Indonesia.

Jl. A.H. Nasution No.105, Cibiru, Bandung 40614, Indonesia

Email: dealitasalsabila01@gmail.com

\section{Dini Arlina}

Jurusan Pendidikan Guru Madrasah Ibtidaiyah, Fakultas Tarbiyah dan Keguruan.

Universitas Islam Negeri Sunan Gunung Djati, Bandung, Indonesia.

Jl. A.H. Nasution No.105, Cibiru, Bandung 40614, Indonesia.

Email : naanona25@gmail.com

\section{Delfianti Azzahra}

Jurusan Pendidikan Guru Madrasah Ibtidaiyah, Fakultas Tarbiyah dan Keguruan.

Universitas Islam Negeri Sunan Gunung Djati, Bandung, Indonesia.

Jl. A.H. Nasution No.105, Cibiru, Bandung 40614, Indonesia.

Email : delfiantiazzahra1001@gmail.com 